Original Research

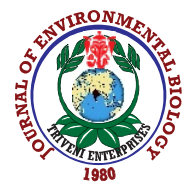

DOI : http://doi.org/10.22438/jeb/41/2/MRN-1033
Journal Home page : www.jeb.co.in $\star$ E-mail : editor@jeb.co.in

Journal of Environmental Biology

$\mathrm{JEB}$

p-ISSN: 0254-8704

-ISSN: 2394-0379

CODEN: JEBIDP
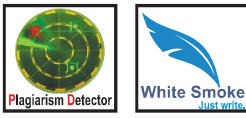

\title{
Effect of Roundup 41\% (glyphosate) on blood serum biochemical parameters of freshwater fish, Rasbora daniconius
}

\author{
T.L. Kharat*, K.B. Rokade and K.B. Shejule \\ Department of Zoology, Dr. Babasaheb Ambedkar Marathwada University, Aurangabad-431 004, India \\ *Corresponding Author Email : tkharat@rediffmail.com
}

Abstract

Aim : The present study was carried out to investigate the impact of Roundup $41 \%$ (glyphosate) on serum enzymes, like aminotransferases activity (ALT andAST), alkaline phosphates (ALP), total protein and glucose of fresh water fish, Rasbora daniconius.

Methodology : $L_{50}$ of glyphosate for $R$. daniconius was calculated by static bioassays and recorded as $5.6 \mathrm{ppm}$ at $96 \mathrm{hr}$. The fish were exposed to sub-lethal concentration $\left(1 / 10^{\text {th }} 96 \mathrm{hr}\right.$ $\mathrm{LC}_{50}$ ) of glyphosate for a period of 7, 14, 21 and 28 days. The serum ALT, AST, ALP, glucose and total protein were determined by standard methods.

Results : Statistically important differences were observed in alanine aminotransferase (ALT), aspartate aminotransferase (AST), alkaline phosphatase (ALP), total protein and glucose levles. ALT, AST and ALP values were significantly higher $(p<0.05)$ in treated group, compared with the control group. There was also a significant increase $(p<0.05)$ in the level of serum glucose while the reduced amount of protein content as compared to control fish.

Interpretation : Increased metabolic enzymes, protein metabolism and hyperglycemia in the serum may be a possible indicator of liver damage caused by Roundup $41 \%$ (glyphosate) exposure in fish, Rasbora daniconius.

Key words: Aminotransferases activity, Glyphosate, Rasbora daniconius, Roundup 41\%, Serum enzymes, Toxicity

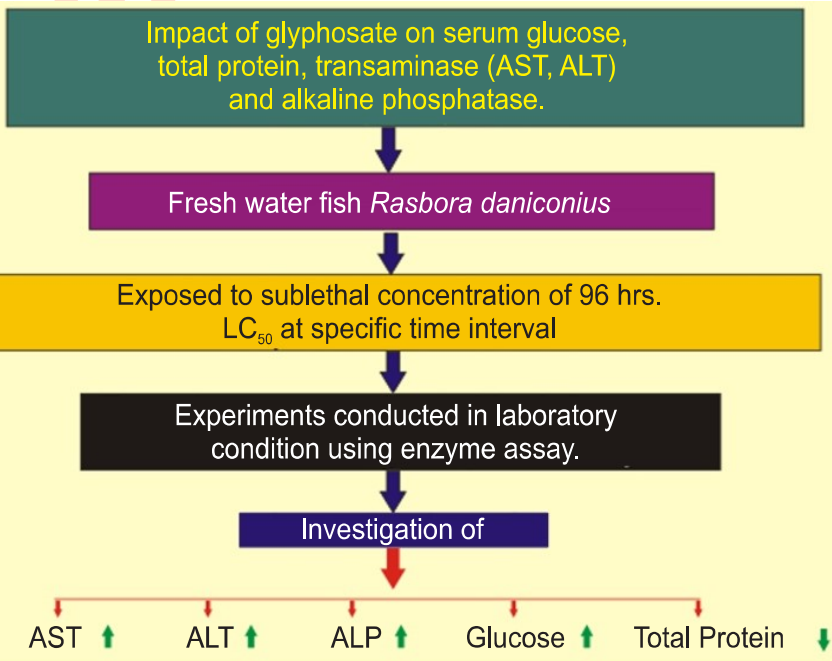

Increased metabolic enzymes, protein metabolism and hyperglycemia in serum may be possible indicator of liver damage caused by glyphosate (Roundup, 41\%) exposure in fish, Rasbora daniconius.

How to cite : Kharat, T.L., K.B. Rokade and K.B. Shejule: Effect of Roundup 41\% (glyphosate) on blood serum biochemical parameters of freshwater fish, Rasbora daniconius. J. Environ. Biol., 41, 222-227 (2020). 


\section{Introduction}

Aquatic ecosystems have gained a lot attention because of hazardous agrochemicals that cause water pollution all around the world. These chemicals are pesticides, herbicides which include halogenated polycyclic hydrocarbons and food additives (Ibeto and Okoye, 2010). Contamination in aquatic ecosystem pose a serious problem to non-target species like fishes, which are continuously exposed to pesticides as a toxicant not only in lethal but also in sub-lethal concentrations cause drastic consequence resulted by agricultural practices (Parvez et al., 2005). Herbicide has long been known as hazardous toxicants found in the aquatic environment.

They are used extensively in agriculture and public health practices and are gaining significant importance due to their ability to control crop and aquatic weeds (Abu-Darwish et al., 2011). Glyphosate, chemically known as isopropyl amine salt of $N$ - phosphonomethyl glycine, is a post-emergent herbicide most commonly used in several types of practices. The most known worldwide commercial names for glyphosate is Roundup ${ }^{\mathrm{TM}}$ (Giesy et al., 2000). Agricultural run-off near water bodies is the major source of deposition of herbicides in aquatic ecosystem (Aktars et al., 2009). Biochemical blood parameters are commonly used for investigating the sub-lethal effects in fish exposed to toxic substances. Fishes being the first level of consumers in the aquatic ecosystem are accepted as bio-indicator to study the health of an aquatic ecosystem as they are directly or indirectly exposed to chemicals. Blood is highly susceptible to changes in the aquatic habitat and is a good indicator of aquatic toxicity (Diego martin Joffre et al., 2013).

Serum metabolic enzymes like alanine transaminase (ALT), aspartate transaminase (AST) and alkaline phosphatase (ALP) are important serum markers to detect the health of animal (Inyang et al., 2013). Alkaline phosphatase is a poly functional enzyme and considered as a biomarker due to its adaptive response to cytotoxic and genotoxic effects of xenobiotics (Samanta et al., 2013), and also plays an important role in transport of metabolites across the membranes. In addition, aminotransferases AST and ALT are the most significant enzymes involved in protein and amino acid metabolism (Glusczak et al., 2011). The other serum biomarkers such as glucose and total protein are commonly used to investigate the health of animals exposed to environmental stresses (Inyang et al., 2014). Therefore, assessing enzyme levels in fish seem to be a promising tool as an indicator of chemical intoxication. Freshwater fish, Rasbora daniconius is selected as a modal organism due to its greater sensitivity for evaluating toxicity, as it is easily available, easily acclimatized in laboratory condition and easily available. The aim of the present study was to investigate the effect of serum biochemical parameters including enzyme alanine transaminase, aspartate transaminase, alkaline phosphatase, total protein and glucose in freshwater fish, $R$. daniconius exposed to herbicide Roundup $41 \%$ (glyphosate) over sublethal concentration $\left(1 / 10^{\text {th }}\right.$ of $96 \mathrm{hr} \mathrm{LC}_{50}$ ) for 7,14, 21 and 28 days.

\section{Materials and Methods}

Sample collection and analysis: Freshwater fish, Rasbora daniconius were collected from Godavari river at Kaigaon village $45 \mathrm{~km}$ away from Aurangabad city in Maharashtra. It is a commonly occurring freshwater fish available in local ponds and rivers. Fishes were acclimatized under laboratory conditions for 1 week in glass aquaria. The fishes were fed with commercially available fish mash. Fish of same size $(6-7 \mathrm{gm}$ and $5-7 \mathrm{~cm})$, irrespective of sexes were selected for the experiment.

Batch of 10 healthy fishes were exposed to different concentration of herbicide Roundup 41\% (glyphosate) to calculate the $\mathrm{LC}_{50}$ value, as determined 5.6ppm for $96 \mathrm{hr}$ by Finney`s Probit analysis (Finney, 1971). Four group of fishes were exposed to sublethal concentration of (1/10th $\left.96 \mathrm{hrs} \mathrm{LC}_{50}\right) 0.56 \mathrm{ppm}$ of Roundup $41 \%$ (glyphosate) for $7,14,21$ and 28 days, respectively, while another group served as control. At the end of experiment, blood samples were taken immediately from caudal vein. Blood samples were centrifuged at $3000 \mathrm{rpm}$ for $10 \mathrm{~min}$ and extracted serum samples were stored at $-20^{\circ} \mathrm{C}$ prior to further analysis.

\section{Serum biochemical analyses}

Aspartate aminotransferase: AST catalyses the reaction between a-oxoglutarate and L-aspartate to give L-glutamate and oxaloacetate. Serum AST was assayed by the method of Reitman and Frankel (1957). AST in the sample was estimated by monitoring the concentration of oxaloacetate hydrazine formed with 2,4-dinitrophenylhydrazine and absorbance was read at $545 \mathrm{~nm}$.

Alanine aminotransferase: The principle for this assay is that ALT catalyses the reaction between a-oxoglutarate and L-alanine to give L-glutamate and pyruvate. SerumALT was assayed by the method of Reitman and Frankel (1957). The concentration of ALT was measured by monitoring the concentration of pyruvate hydrazine formed with 2,4-dinitrophenylhydrazine and absorbance was read at $545 \mathrm{~nm}$.

Alkaline phosphatase: ALP was estimated by monitoring by the concentration of p-nitrophenyl phosphate. $\mathrm{A} 0.5 \mathrm{ml}$ of $\mathrm{p}$-nitrophenyl phosphate and $0.5 \mathrm{ml}$ of glycine buffer were taken in test tubes labelled as blank, control and sample. The tubes were placed in a water bath at $37^{\circ} \mathrm{C}$ for $5 \mathrm{~min}$. Then $0.1 \mathrm{ml}$ of sample added to the test and $0.1 \mathrm{ml}$ of distilled water to the blank. The test tubes were incubated at $37^{\circ} \mathrm{C}$ for $30 \mathrm{~min}, 10 \mathrm{ml}$ of $0.02 \mathrm{~N} \mathrm{NaOH}$ was added to each test tube. The tubes were mixed well. The absorbance was measured at $405 \mathrm{~nm}$ (Bergmeyer, 1972) and the results were expressed in $\mathrm{UII}^{-1}$.

Total protein: Protein content in the samples was estimated by the method of Lowry et al. (1951) using bovine serum albumin as standard and the values were expressed as $\mathrm{mg}$ protein $\mathrm{I}^{-1}$. The absorbance was read at $620 \mathrm{~nm}$ against a blank.

Blood glucose: Blood glucose levels in the samples were 
determined by colorimetric method as described by Nelson and Somogyi (1952) and expressed as mg glucose $100 \mathrm{ml}^{-1}$ of blood and the absorbance was read at $540 \mathrm{~nm}$ against a blank.

Statistical analysis: The mean values of biochemical parameters for the control and experimental group of fish were analysed for statistical significance by student 't' test at 0.01 and 0.05 level of significance.

\section{Results and Discussion}

Roundup 41\% (glyphosate) is commonly used herbicide by the farmers, commercially formulated product (isopropyl amine salt of $\mathrm{N}$ - phosphonomethyl glycine) which are toxic to fish and to some other aquatic organisms (Servizi et al., 1997). Many hazardous chemicals reaching the aquatic ecosystem cause adverse effect on the aquatic animals and deleterious changes that disrupt the metabolic activity and physiological levels (Das and Mukerjee, 2000). Biochemical changes in serum are often regarded as the most significant indicator of physiological status of fish (Inyang et al., 2014). Enzyme activities affect various chemical and biological reactions in the body of fish and it is commonly used as an early warning of pollutant toxicity in animals (Dutta and Areids, 2003). Evaluation of enzymatic activities in the serum of aquatic organisms is one of the important tools in toxicological assessment (Oluah et al., 2005). The use of fish species in toxicity based studies is now being widely used due to their sensitivity to toxic chemicals resulting from agricultural processes along with surface run-off (Diego martin jofre etal., 2013) and can be considered as indicators of xenobiotic contamination (Vander Oost et al., 2003). In the present study, the $96 \mathrm{hr} \mathrm{LC}$ of glyphosate for $R$. daniconius was estimated as $5.6 \mathrm{ppm}$ (Table1). The present study revealed changes in aspartate aminotransferases, alanine aminotransferases, alkaline phosphatase, total protein and glucose content in serum of treated fish (Table 2). AST, ALT and ALP activities showed significant $(p<0.05)$ increase in duration-dependent manner (Table 2).

In Rasbora daniconius, the serum AST and ALT activity increased as compared to control. The AST and ALT activity was found to increase with increasing exposure period. Aspartate aminotransferase and alanine aminotransferase activity in blood exposed to control and glyphosate exposure showed increasing trend. There is an increase in the percentage variation of AST and ALT with increasing exposure period due to its toxic effect. In the present study, observed that percent changes in the blood serum AST increased at 7 days exposure in sub-lethal concentrations of glyphosate when compared to control by $9.5 \%$, further exposure for 14 day, 21 day and 28 days, the AST level gradually increased by $18.23 \%, 29.57 \%$ and $38.39 \%$, respectively. These finding were found to be highly significant at $(p<0.05)$. Alanine aminotransferase activity increased on day 7 by $9.29 \%$ as compared to control, and further exposure to glyphosate, ALT activity increased by $27.87 \%, 33.99 \%$ and $44.87 \%$ on 14,21 and 28 day, respectively (Table 2). Similarly, serum ALP level in exposed fish also increased at 7 day by $18.9 \%$ as compared to control and further on 14 day, 21 day, 28 day ALP level increased by $34.35 \%, 55.32 \%$ and $69.64 \%$, respectively (Table 2 ).

Protein content in fish treated with glyphosate decreased by $22.47 \%$ on $7^{\text {th }}$ day, $39.50 \%$ on $14^{\text {th }}$ day, $50.72 \%$ on $21^{\text {st }}$ day and $61.44 \%$ on $28^{\text {th }}$ day as compared to the control whereas glucose level increased by $10.93 \%$ on day $7,19.69 \%$ on day $14,30.86 \%$ on day 21 and $38.28 \%$ on day 28 , respectively, as compared to the control (Table 2). Enzymes of blood serum have been considered as relevant to stress indicator. Therefore, activities of serum ALT, AST and ALP have been commonly used for the detection of tissue damage caused by environmental pollution. In the present study, serum AST, ALT and ALP activity were significantly increased in all the treated groups as compared to control with highest induction being shown on 21 day treatment group although 28 day higher by damage of cell. Therefore, alterations in the activity of these enzymes are a sensitive biomarker for damage to cell membranes (Gholizadeh Zare Tavana et al., 2018). The increased enzyme activity (AST) may be attributed to enhanced transamination for transfer of more amino acids into TCA cycle to meet high energy under toxic stress. These values demonstrate liver damage due to xenobiotic exposure and is in agreement with the study of Loro et al. (2015) who reported increased AST and ALT activities in Cyprinus carpio exposed to glyphosate at $3.5,7$ and $14 \mathrm{mg} \mathrm{l}^{-1}$. Enhanced ALT and AST levels in serum indicate stress in fish. Further, enhanced levels of these enzyme activities in the extracellular fluid or serum is a sensitive indicator of even minor cellular damage (Palanivelu et al., 2005) and indicate stress-based tissue impairment. Alkaline phosphatase is a polyfunctional enzyme that plays an important role in transport of minerals to the skeleton of aquatic animals. Furthermore, increased ALP may be related to hepatocellular damage in tissue due to higher metabolic activities to meet high energy demand.

Increased activity in the investigated fish under glyphosate exposure in the present study indicated toxicity to tissues or organs leading to release of the enzyme into the serum or blood circulation and the presence of these metabolites acts as intermediate to Krebs' cycle. Both AST and ALT also play a vital role in protein and carbohydrate metabolism. Therefore, they appear to be reliable indicator in demonstrating liver damage caused by pesticides (Gholami-Seyedkolaei et al., 2013). In general, the results of ALT, AST and ALP indicate degenerative changes and hypofunction of liver as toxicants affect hepatocytes. Therefore, enhanced levels of these enzyme activities in serum of $R$. daniconius is mainly due to the leakage of these enzymes from the liver cytosol into the blood stream as a result of liver damage by glyphosate which gives an indication of hepatotoxicity. Any increase or decrease in the levels ofALT and AST indicate damage to vital organs of fishes (Dhanapakiam et al., 2006). Transaminases are released in blood stream from the damaged organs and their increased activities in the blood serum indicate the degree of tissue damage (Kristofferson et al., 1974). Several reports are available on the increase as well as decrease or more effect in the enzyme activities of organs and 
Table 1: $96 \mathrm{hr}$ lethal dose $\left(\mathrm{LC}_{50}\right)$ of glyphosate for fish, Rasbora daniconius

\begin{tabular}{lllll}
\hline $\begin{array}{l}\text { Concentration of } \\
\text { glyphosate in ppm }\end{array}$ & $\begin{array}{l}\text { No. of fish } \\
\text { used }\end{array}$ & $\begin{array}{l}\text { Corrected \% } \\
\text { of mortality }\end{array}$ & $\begin{array}{l}\text { Log of conc. } \\
\text { to base 10 }\end{array}$ & $\begin{array}{l}\text { Probit } \\
\text { analysis }\end{array}$ \\
\hline 5.0 & 10 & 30 & 0.6990 & 4.477 \\
5.2 & 10 & 30 & 0.7160 & 4.478 \\
5.4 & 10 & 40 & 0.7324 & 4.747 \\
5.6 & 10 & 50 & 0.7482 & 5 \\
5.8 & 10 & 60 & 0.7634 & 5.253 \\
6.0 & 10 & 70 & 0.7782 & 5.521 \\
\hline
\end{tabular}

Table 2: Values of blood serum enzymes and biochemical parameter of fish, Rasbora daniconius exposed to sub-lethal concentration (0.56ppm) of glyphosate

\begin{tabular}{|c|c|c|c|c|c|}
\hline $\begin{array}{l}\text { Exposure period/ } \\
\text { Biochemical parameters }\end{array}$ & AST $\left(\mathrm{Ul}^{-1}\right)$ & ALT $\left(\mathrm{UI}^{-1}\right)$ & $\operatorname{ALP}\left(\mathrm{Ul}^{-1}\right)$ & $\begin{array}{l}\text { Total protein } \\
\left(\mathrm{mg} \mathrm{l}^{-1}\right)\end{array}$ & Glucose $\left(\mathrm{mg} \mathrm{l}^{-1}\right)$ \\
\hline Control & $\begin{array}{l}37.19 \\
\pm 1.42^{*}\end{array}$ & $\begin{array}{l}17.65 \\
\pm 0.85^{\star *}\end{array}$ & $\begin{array}{l}44.97 \\
\pm 3.15^{*}\end{array}$ & $\begin{array}{l}4.85 \\
\pm 1.57^{\star *}\end{array}$ & $\begin{array}{l}62.30 \\
\pm 3.39^{* *}\end{array}$ \\
\hline \multirow[t]{2}{*}{7 days } & $\begin{array}{l}40.75 \\
\pm 1.78^{*}\end{array}$ & $\begin{array}{l}19.29 \\
\pm 0.84^{* *}\end{array}$ & $\begin{array}{l}53.47 \\
\pm 1.62^{*}\end{array}$ & $\begin{array}{l}3.76 \\
\pm 0.66^{* *}\end{array}$ & $\begin{array}{l}69.12 \\
\pm 1.85^{\star *}\end{array}$ \\
\hline & $9.5 \% \uparrow$ & $9.29 \% \uparrow$ & $18.9 \% \uparrow$ & $22.47 \% \downarrow$ & $10.93 \% \uparrow$ \\
\hline \multirow[t]{2}{*}{14 days } & $\begin{array}{l}43.94 \\
\pm 2.12^{*}\end{array}$ & $\begin{array}{l}22.57 \\
\pm 2.25^{\star *}\end{array}$ & $\begin{array}{l}60.42 \\
\pm 3.88^{*}\end{array}$ & $\begin{array}{l}2.94 \\
\pm 1.39^{* *}\end{array}$ & $\begin{array}{l}74.57 \\
\pm 1.56^{\star *}\end{array}$ \\
\hline & $18.23 \% \uparrow$ & $27.87 \% \uparrow$ & $34.35 \% \uparrow$ & $39.50 \% \downarrow$ & $19.69 \% \uparrow$ \\
\hline \multirow[t]{2}{*}{21 days } & $\begin{array}{l}45.19 \\
\pm 2.78^{*}\end{array}$ & $\begin{array}{l}23.57 \\
\pm 2.45^{\star *}\end{array}$ & $\begin{array}{l}69.85 \\
\pm 6.20^{*}\end{array}$ & $\begin{array}{l}2.39 \\
\pm 1.40^{* *}\end{array}$ & $\begin{array}{l}81.53 \\
\pm 3.07^{\star *}\end{array}$ \\
\hline & $29.57 \% \uparrow$ & $33.99 \% \uparrow$ & $55.32 \% \uparrow$ & $50.72 \% \downarrow$ & $30.86 \% \uparrow$ \\
\hline \multirow[t]{2}{*}{28 days } & $\begin{array}{l}51.47 \\
\pm 3.60^{*}\end{array}$ & $\begin{array}{l}25.57 \\
\pm 3.40^{\star \star}\end{array}$ & $\begin{array}{l}76.29 \\
\pm 6.12^{*}\end{array}$ & $\begin{array}{l}1.87 \\
\pm 0.14^{\star *}\end{array}$ & $\begin{array}{l}86.15 \\
\pm 3.19^{\star \star}\end{array}$ \\
\hline & $38.39 \% \uparrow$ & $44.87 \% \uparrow$ & $69.64 \% \uparrow$ & $61.44 \% \downarrow$ & $38.28 \% \uparrow$ \\
\hline
\end{tabular}

Values are mean of five replicates \pm S.D; ${ }^{*}$ indicates significant $(p<0.05)$ and ${ }^{* *}$ indicates significant $(p<0.01)$.

blood of fish exposed to pesticides (Kumavan et al., 2011). Some authors have reported herbicide toxicity in fish, especially concerned with metabolic enzymes in response to glyphosate exposure (Gholami-Seyedkolaei et al., 2013; Glusczak et al., 2011). Similarly, increased AST and ALT activity in fish Cyprinus carpio exposed to glyphosate has been reported. Alterations of these enzymes (ALT, AST and ALP) in fish as a result of toxic effect in serum of fish have been reported (Aly and EL-Gendy 2015; Sunmonu and Oloyede, 2012). Similar results were reported in C. carpio exposed to dimethoate (Rezaei Shadegan and Banaee, 2018). Therefore, changes in the activity of biochemical enzyme in serum may be considered as sensitive biomarkers in eco-toxicological studies as prediction of herbicide toxicity in aquatic animals.

In the present study, the total protein content in the serum of all the exposure periods was reduced significantly compared to control. The decrease in protein content in serum might be due to an induced effect of glyphosate toxicity in Rasbora daniconius. Low serum protein levels in $R$. daniconius exposed to glyphosate for 28 days indicate protein mobilization, since a high energy demand may increase protein catabolism. Glusczak et al. (2006) reported that Piavas exposed to Roundup exhibited hypoproteinemia. Similar results were also reported by David et al. (2004). Biochemical parameters are useful tool for understanding the impact of pesticides in fish species and indicated alterations under different stress conditions (Anamika Singh and Ajay Singh, 2017; Kreutz et al., 2011; Modesto and Martinez, 2010). In the present finding, glucose content in the serum increased at all exposure periods and was found highest on day 28 . The increased serum glucose level indicates increased energy demand. Increase in serum glucose levels in fish under stress was earlier reported by Cicik and Engin (2005). In conclusion, the findings of the present study provide a better understanding of ectoxicological endpoint of glyphosate that can be used at a safer level in the aquatic environmentin order to protect its habitat. 


\section{Acknowledgments}

The first author is thankful to the University Grant Commission, Government of India, New Delhi for providing financial assistance through Rajiv Gandhi National Research Fellowship and also to the Head, Department of Zoology, Dr. Babasaheb Ambedkar Marathwada University, Aurangabad for providing laboratory facilities for carrying out research work.

\section{References}

Abu-Darwish, M.S., A.H. Al-Fraihat, S.Y.A. Al-Dalain, F.U. Afifi and J. A. Al-Tabbal: Determination of essential oils and heavy metal accumulation in Salvia officinalis cultivated in three intra-raw spacing in Ash-shoubak. Jordan. Int. J. Agric. Biol., 13, 981-985 (2011).

Aktar, W., D. Sengupta and A. Chaudhuri: Impact of pesticides uses in agriculture: Their benefits and hazards. Interdiscipl. Toxicol., 2 , 1-12 (2009)

Aly and K. El-Gendy: Impact of parathion exposure on some biochemical parameters in rabbit as a non-targeted organism. Alexandna $\mathrm{J}$. Med., 15, 11-17 (2015)

Anamika Singh and Ajay Singh: Studies on toxicity stress, behavioural alterations and biochemical changes induced by glyphosate herbicide on the freshwater fish, Channa punctatus (Bloch). Int. J. FoodAgricul. Veter. Sci., ISSN: 2177 (online) 7, 39-48 (2017).

Bawa, V., J.K. Kondal, S.S. Hundal and H. Kaur: Biochemical and histopathological effects of glyphosate on the liver of Cyprinus Carpio (Linn). Amer. J. Life Sci., Special Issue: Environ. Toxicol., 5, 71-80 (2017)

Begum, G.: Carbofuran insecticide induced biochemical alterations in liver and muscle tissues of the fish Clarias batrachus (Linn) and recovery response. Aquatic Toxicol., 66, 83-92 (2004).

Bergmeyer, H. U.: Methods of Enzymatic Analysis. Vol. 4, Academic Press, New York and London, pp. 727-771(1972).

Cicik, B. and K. Engin: The effects of cadmium on levels of glucose in serum and glycogen reserves in the liver and muscle tissues of Cyprinus carpio (L. 1758). Turk J. Vet. Anim. Sci., 29, 113-117 (2005).

Crestani, M., C. Menezes, L. Glusczak, D. Dos Santos Miron, R. Lazzari, M.F. Duarte and V.P. Vieira: Effects of clomazone herbicide on hematological and some parameters of protein and carbohydrate metabolism of silver catfish Rhamdia quelen. Ecotoxicol. Environ. Saf., 65, 48-55 (2006)

Das, B.K. and S.C. Mukharjee: Sub-lethal effects of organophophorus pesticides (Quinalphose and Dimethoate) on selected blood parameters of Labeo rohita (Ham fingerlings). The Asian Fisher. Sci. J., 13, 225-233 (2000)

Das, B.K. and S.C. Mukherjee: Toxicity of cypermethrin on Labeo rohita fingerlings: Biochemical, enzymatic and hematological consequences. Comp. Biochem. Physiol. Part C Toxicol. Pharmacol., 134, 109-121 (2003).

David, M., S.B. Mushigeri, R. Shivakumar and G.H. Philip: Response of Cyprinus carpio (Linn) to sub-lethal concentration of cypermethrin: Alterations in protein metabolic profiles. Chemosphere, 56, 347352 (2004).

Diego martin jaguar, M. Jose Germano Garcia, R. Slcedo, M. Morales, M. Alvarez, D. Enriz and F. Giannini: Fish toxicity of commercial herbicides formulated with glyphosate. J. Environ. Analy. Toxic., 4, 199, 2161-0525 (2013).

Dutta, H.M. and D.A. Areids: Effects of endosulfan on brain acetyl cholinestarate activity in juvenile blue gill sunfish. Environ. Res. 91, 157-162 (2003).

Dhanapakiam, P., V.K. Ramasamy and J. Mini Joseph: Changes in the level of transaminases in Indian major carp, Labeo rohita exposed to sub-lethal concentration of tannery and distillery effluent. $J$. Environ. Biol., 27, 567-70 (2006)

Finney, D.J. Probit Analysis. $3^{\text {rd }}$ Edn., Cambridge University Press, London, P: 20 (1971).

Gholami-Seyedkolaei, S. J., A. Mirvaghefi, H. Farahmand and A. A. Kosari: Effect of a glyphosate-based herbicide in Cyprinus carpio: Assessment of acetyl cholinesterase activity, hematological responses and serum biochemical parameters. Ecotoxicol. Environ. Saf., 98, 135-141 (2013).

Gholizadeh Zare Tavana, B., M. Banaee, A.Y. Jourdehi, B. N. Haghi and M. Seyed Hassani: Effects of selenium (Sel-Plex) supplement on blood biochemical parameters of juvenile Siberian sturgeon (Acipenser baerii). Iranian J. Fishe. Sci., 17, 300-312 (2018).

Giesy, J.P., S. Dobson and K.R. Solomon: Ecotoxicological risk assessment for Roundup ${ }^{\circledR}$ herbicide. Rev. Environ. Contam. Toxicol., 167, 35-120 (2000).

Gluszak, L., M.D. Santos, M. Crestani, M.B. da Fonseca, F. de Araujo Pedron, M.F. Duarte and V.L.P. Vieira: Effect of glyphosate herbicide on acetylcholinestrase activity and metabolic and hematological parameters in piava (Leporinu sobtusidens). Ecotoxicol. Environ. Saf., 6, 237-241 (2006).

Glusczak, L., V.L. Loro, A.B.S. Mor. Prettoaes, A. Raabe, M.F. Duarte, M. B. da Fonseca, C.C. de Menezes and D.M. Valladão: Acute exposure to glyphosate herbicide affects oxidative parameters in piava (Leporinus obtusidens). Arch. Environ. Contam. Toxicol., 61, 624-30 (2011).

Ibeto, C.N. and C.O.K. Okoye: High levels of heavy metals in blood of the urban population in Nigeria. Res. J. Environ. Sci., 4, 371-382 (2010).

Inyang, I.R., E.R. Daka and E.N. Ogamba: Effects of sub-lethal concentrations of diazinon on total protein and transaminase activities in Clarias gariepinus. Curr. Res. J. Biol. Sci., 2, 390-395 (2010).

Inyang, I.R., I.E.K. Ekweozor and A. Ollor: Physiological effects of diazinon on Clarias gariepinus. BEST Journal, 1, 171-176 (2014).

Jyothi, B. and G. Narayan: Pesticide alterations of non-protein nitrogenous constituents in the serum of a fresh water cat fish Clarias batrachus (Linn). Indian J. Exper. Biol., 38, 1058-61. (2000)

Kumavan, S.S., C. Kavitha, M. Ramesh and T. Grumnt: Toxicity studies of nonylphenol and octylphenol: Hormonal haematological and biochemical effects in Clarias gariepinus. J. App. Toxicol., 31, 1-11 (2011).

Kreutz, L.C., L.J.G. Barcellos, S.F. Valle, T.O. Silva, D.Anziliero, E.D. Santos, M. Pivato and R. Zanatta: Altered hematological and immunological parameters in silver catfish (Rhamdia quelen) following short term exposure to sub-lethal concentration of glyphosate. Fish Shellfish Immunol., 30, 51-57(2011).

Kristofferson, R., S. Broberg, A. Oikari and M. Pekkarinen: Effect of sublethal concentration of phenol on some blood enzyme activities in the pike (Esox lucius L.) in brackish water. Ann. Zool. Fennic, 11, 220-223 (1974)

Loro, V.L., L. Glusczak, B.S. Moraes Leal, C.A.M.C. Menezes and C.R. Murussi: Glyphosate-based herbicide affects biochemica parameters in Rhamdia quelen (Quoy \& Gaimard, 1824 and) Leporinus obtusidens (Valenciennes, 1837). Neotrop. Ichthyol., 13, 229-236(2015). 
Lowry, O.H., N.J. Rosebrough, A.L. Farr and R.J. Randall: Protein measurement with the folin phenol reagent. J. Biol. Chem., 193, 265-275 (1951).

Oluah, N.S., J.C. Ezigbo and N.C. Anya: Effect of exposure to sub-lethal concentrations of Gammalin 20 and Actellic $25 \mathrm{EC}$ on the liver and serum lactate dehydrogenase activity in the fish Clarias albopunctaus. Anim. Res. Int., 2, 231-234 (2005).

Palanivelu, V., K. Vijayavel, S.E. Subramanian and M.P. Balasubramanian: Influence of insecticidal derivative (Cartap Hydrochloride) from marine polychaete on certain enzyme systems of freshwater fish Oreochromis mossambicus. J. Environ. Biol., 26, 191-196 (2005)

Parvez, S. and S. Raisuddin: Protein carbonyls: Novel biomarkers of exposure to oxidative stress-inducing pesticides in freshwater fish Channa punctata (Bloch). Environ. Toxicol. Pharmacol., 20, 112$117(2005)$

Reitman, S. and S. Frankel: A colorimetric method for the determination of serum glutamic oxaloacetic and glutamic pyruvate transminase. Am. J. Clin. Pathol., 28, 56-63 (1957).

Rezaei Shadegan, M. and M. Banaee: Effects of dimethoate alone and in combination with Bacilar fertilizer on oxidative stress in common carp, Cyprinus carpio. Chemosphere, 208, 101-107 (2018).

Salbego, J., A. Pretto, C.R. Gioda, C.C. de Menezes, R. Lazzari, J. Radünz Neto, B. Baldisserotto and V.L. Loro: Herbicide formulation with glyphosate affects growth, acetylcholinesterase activity and metabolic and hematological parameters in Piava (Leporinus obtusidens). Arch. Environ. Contamin. Toxicol., 58, 740-745(2010).

Samanta, P., S. Pal, A.K. Mukherjee, T. Senapati and A.R. Ghosh:
Evaluation of enzymatic activities in liver of three teleostean fishes exposed to commercial herbicide, Almix 20 WP. Proc. Zool. Soc (2013). DOI: 10.1007/s12595-013-0086-z

Sancho, E., M.D. Ferrando, C. Fernández and E. Andreu.: Liver energy metabolism of Anguilla anguillaafter exposure to fenitrothion. Ecotoxicol. Environ. Saf., 41, 168-175(1998)

Sancho, E., J.J. Ceró and MD. Ferrando: Cholinesterase activity and hematological parameters as biomarkers of sub-lethal molinate exposure in Anguilla anguilla. Ecotoxicol. Environ. Saf., 46, 81-86 (2000).

Sastry, K.V. and K. Subhadra: In-vivo effects of cadmium on some enzyme activities in tissues of freshwater catfish, Heteropnuestes fossilis. Environ. Res., 36, 32-45 (1985).

Servizi, J.A., R.W. Gardan and D.W. Martens: Acute toxicity of Garion and Roundup herbicides to salmon, Daphnia and trout. Bull. Environ. Contam. Toxicol., 33, 355-361 (1997).

Somogyi, M.: Notes on sugar determination. J. Biol. Chem., 195, 19-23 (1952).

Sunmonu, T.O. and O.B. Oloyede.: Monoclotophos-induced enzymatic charges as toxicity biomarkers in Winster rat liver. Agricul. Biol. J. NorthAmerica, 37, 302-305 (2012).

Vander Oost, R., J. Beyer and NPE Vermeulen: Fish bioaccumulation and biomarkers in environmental risk assessment: A review. Environ. Toxicol. Pharmacol., 13, 57-149 (2003).

Venugopal, N.B.R.K. and S.L.N Reddy: In-vivo effects of cadmium chloride on certain aspects of protein metabolism in tissues of a freshwater field crab, Barytelphusa guerini. Bull. Environ. Contam. Toxicol., 46, 583-590 (1991). 